\title{
Kirtilkrabbamein í botnlanga á Íslandi 1990-2009 - lýðgrunduð rannsókn
}

Halla Viðarsdóttir, læknir ${ }^{1}$ Jón Gunnlaugur Jónasson, meinafræðingur ${ }^{2,3,4}$ Páll Helgi Möller, læknir ${ }^{1,3}$

\section{ÁGRIP}

Tilgangur: Kirtilkrabbamein í botnlanga er innan við 0,5\% krabbameina í meltingarvegi. Tilgangur rannsóknarinnar var að skoða nýgengi, einkenni, meinafræði, meðferð og horfur sjúklinga hér á landi.

Efniviður og aðferðir: Rannsóknin var afturskyggn og náði til allra sjúklinga sem greindust með kirtilkrabbamein í botnlanga á Íslandi 1990-2009. Skoðaðir voru faraldsfræðilegir pættir, meðferð og lifun. Öll vefjasýni voru skoðuð og meinafræði endurmetin. Meðaleftirfylgni lifandi greindra var 15 mánuðir (bil: 0-158).

Niðurstöður: Alls greindust 22 sjúklingar með kirtilkrabbamein í botnlanga (miðaldur 63 ár, bil: 30-88, 50\% karlar). Aldursstaðlað nýgengi var 0,4/100.000 á ári. Algengasta einkennið var kviðverkur $(n=10)$ en átta sjúklingar höfðu klínísk einkenni botnlangabólgu. Flestir sjúklingar greindust í aðgerð eða við vefjagreiningu en einn við krufningu. Fimm sjúklingar fóru í botnlangatöku og 11 í brottnám á hægri hluta ristils. Einn sjúklingur fór ekki í skurðaðgerð og hjá premur var eingöngu tekið vefjasýni. Tólf sjúklingar fengu krabbameinslyfjameðferð, par af sjö við dreifðum sjúkdómi. Átta sjúklingar höfðu kirtilkrabbamein, sjö slímkrabbamein, prír sigðfrumukrabbamein, einn blandað krabbalíkisæxli af slímfrumugerð og slímkrabbameini, einn kirtilkrabbamein með sigðfrumukrabbameini og tveir höfðu slímæxli af óvissri illkynja hegðan. Í átta tilvikum var æxlið upprunnið í kirtilsepaæxli. Flestir höfðu sjúkdóm á stigi IV ( $n=13)$, 3 á stigi III, 3 á stigi II og 3 á stigi I. Skurđdauđi var 4,8\% (n=1). Sjúkdómssértæk fimm ára lifun var $54 \%$ en heildar fimm ára lifun $44 \%$. Ályktun: Kirtilkrabbamein í botnlanga eru sjaldgæf. Allir sjúklingar greindust fyrir tilviljun. Rúmlega helmingur sjúklinga var með dreifðan sjúkdóm við greiningu.

1Skurðlækningadeild Landspítala, ${ }^{2}$ rannsóknarstofu í meinafræði á Landspítala, a Landspitala, ${ }^{4}$ Krabbameinsskrá Íslands.

Fyrirspurnir: Páll Helgi Möller, pallm@landspitali.is

Barst: 18. mars 2011, - sampykkt til birtingar: 15 . september 2011.

Höfundar tiltaka hvorki styrki né hagsmunatengsl.

\section{Inngangur}

Illkynja æxli í botnlanga eru af fjórum megingerðum, hefðbundin kirtilkrabbamein (adenocarcinoma NOS), krabbalíkisæxli (carcinoid tumours), slímkrabbamein (mucinous adenocarcinoma) og blanda af kirtilkrabbameini og krabbalíkisæxli. Í flestum rannsóknum hefur krabbalíkisæxli verið algengast eða allt að 50\% pessara æxla. раð eru pó vísbendingar um að slímkrabbamein og kirtilkrabbamein séu að verða algengari en krabbalíkisæxli. Í rannsókn á 2514 tilfellum í Bandaríkjunum reyndist slímkrabbamein vera algengast, par á eftir komu kirtilkrabbamein og krabbalíkisæxli sem voru einungis $20 \% .{ }^{1}$ Petta er sjaldgæfur sjúkdómur eða einungis um $0,5 \%$ af öllum krabbameinum í meltingarvegi. ${ }^{2}$ Talið er Beger hafi lýst fyrsta tilfellinu árið $1882 .^{3}$ Kirtilkrabbamein í botnlanga hafa áður verið skoðuð hér á landi fyrir árin 1974-1989 og var nýgengi samkvæmt peirri rannsókn 0,2 á hverja 100.000 íbúa á ári. ${ }^{4}$ Talið er að botnlangakrabbamein sé til staðar í um $1 \%$ botnlanga sem sendir eru í meinafræðirannsókn. ${ }^{5}$ Algengast er að sjúklingar séu með einkenni bráđrar botnlangabólgu enda stíflar æxlið oft op botnlangans. Önnur einkenni eru fyrirferð í kvið eða garnastífla. ${ }^{6}$ Í nánast öllum tilfellum er krabbamein í botnlanga greint í aðgerð eða við skoðun á vefjasýni en ekki fyrir aðgerð pó slíkt komi fyrir.7, 8 Meðalaldur sjúklinga samkvæmt rannsóknum hefur verið 55,1-62 ár. ${ }^{4,6,9}$ Í rannsóknum sem birtar hafa verið um kirtilkrabbamein í botnlanga er fimm ára lifun á bilinu 43-55\%.7, 10 Sjúklingar með kirtilkrabbamein hafa verri horfur en sjúklingar með slímkrabbamein samkvæmt mörgum rannsóknum,, , 9 en bent hefur verið á að petta eigi eingöngu við ef sjúkdómurinn er dreifður við greiningu og pað sé pví útbreiðsla sjúkdómsins við greiningu sem skipti máli en ekki vefjagerðin. ${ }^{1}$ Par sem eitlastöðvar botnlanga eru pær sömu og fyrir botnristil (coecum) og dausgarnarenda (terminal ileum) er mælt með brottnámi á hægri hluta ristils sem meðferð við kirtilkrabbameini í botnlanga. ${ }^{6}$ Allmargir sjúklingar með botnlangakrabbamein greinast með æxli annars staðar í líkamanum og í einni rannsókn kom fram tíðni á slíku sem nam 35\%. ${ }^{6}$ Algengast er að slík æxli séu í meltingarvegi, en Nitecki og félagar mæltu með leit að öðrum æxlum við greiningu á krabbameini í botnlanga. ${ }^{6}$ Í íslensku rannsókninni frá 1990 hafði enginn sjúklingur pannig æxli.

Markmið pessarar rannsóknar var að skoða kirtilkrabbamein í botnlanga á Íslandi með tilliti til faraldsfræðilegra pátta, meinafræði, meðferðar og lifunar. Ennfremur að bera niðurstöður saman við fyrri rannsókn á kirtilkrabbameini í botnlanga á Íslandi.

\section{Efniviður og aðferðir}

Rannsóknin var afturskyggn og lýðgrunduð. Upplýsingar um alla sjúklinga sem greindust með krabbamein í botnlanga á tímabilinu 1990-2009 að báđum árum meðtöldum voru fengnar frá Krabbameinsskrá Íslands. Petta 20 ára tímabil var valið par sem áður hefur verið gerð rannsókn á krabbameini í botnlanga fyrir árin 1974-1989. Vefjasýni voru fengin frá rannsóknarstofu í meinafræði á Landspítala og meinafræðideild Fjórðungssjúkrahússins á Akureyri. Öll sýnin voru skoðuð og meinafræðin endurmetin samkvæmt viðurkenndri skilgreiningu Alpjóðaheilbrigðisstofnunarinnar (WHO) af sérfræðingi í meinafræði. ${ }^{15}$ Sjúklingar voru stigaðir 
samkvæmt TNM-stigunarkerfi American Joint Commitee on Cancer (AJCC) (tafla I). ${ }^{11}$ Úr sjúkraskrám sjúklinga voru skráðar eftirfarandi upplýsingar: kyn, aldur við greiningu, einkenni, meðferð, tegund aðgerðar og fylgikvillar. Meðaleftirfylgni sjúklinga

Tafla I. TNM-stigun AJCC fyrir krabbamein i botnlanga. ${ }^{11}$

\begin{tabular}{|c|c|}
\hline \multicolumn{2}{|c|}{ Frumæxli (T) } \\
\hline TX & Ekki hægt að meta frumæxli \\
\hline TO & Engin merki um frumæxli \\
\hline Tis & Innan slímhúðar krabbamein (carcinoma in-situ) \\
\hline $\mathrm{T} 1$ & Æxli vex í slímubeð \\
\hline T2 & ÆExli vex í vöðvalag (muscularis propria) \\
\hline T3 & $\begin{array}{l}\text { Æxli vex í gegnum vöðvalag og inn í hálubeð } \\
\text { eða inn í botnlangahengi }\end{array}$ \\
\hline $\mathrm{T} 4$ & $\begin{array}{l}\text { Æxli vex í gegnum visceral lífhimnu, par á meðal } \\
\text { slímæxli í lífhimnu í neðri hægri fjórðungi } \\
\text { og/eđa vex beint inn í önnur líffæri }\end{array}$ \\
\hline T4a & $\begin{array}{l}\text { ÆExli vex í gegnum visceral lífhimnu, par } \\
\text { á meðal slímæxli i lífhimnu í neðri hægri fjórðungi }\end{array}$ \\
\hline $\mathrm{T} 4 \mathrm{~b}$ & ÆExli vex beint inn í önnur líffæri \\
\hline \multicolumn{2}{|c|}{ Svæðiseitlar (N) } \\
\hline NX & Ekki hægt að meta svæðiseitla \\
\hline No & Engin meinvörp í svæðiseitlum \\
\hline N1 & Meinvörp í 1-3 svæðiseitlum \\
\hline N2 & Meinvörp í 4 eða fleiri svæðiseitlum \\
\hline \multicolumn{2}{|c|}{ Fjarmeinvörp (M) } \\
\hline MO & Engin fjarmeinvörp til staðar \\
\hline M1 & Fjarmeinvörp til staðar \\
\hline M1a & $\begin{array}{l}\text { Fjarmeinvörp í lífhimnu fyrir utan hægri neðri fjórðung, par } \\
\text { á meðal skinuslímhlaup }\end{array}$ \\
\hline M1b & Fjarmeinvörp utan lífhimnu \\
\hline \multicolumn{2}{|c|}{ Proskunargráđa (G) } \\
\hline GX & Ekki hægt að meta proskun æxlis \\
\hline G1 & Slímæxli lággráđu \\
\hline G2 & Meðalvel proskuð \\
\hline G3 & Slímæxli hágráđu \\
\hline G4 & Ósérhæft \\
\hline \multicolumn{2}{|l|}{ Stig } \\
\hline 0 & Tis, NO, MO \\
\hline 1 & $\mathrm{~T} 1, \mathrm{~T} 2, \mathrm{~N} 0, \mathrm{M} 0$ \\
\hline$\| A$ & T3, NO, MO \\
\hline IIB & T4a, No, Mo \\
\hline IIC & $\mathrm{T} 4 \mathrm{~b}, \mathrm{NO}, \mathrm{MO}$ \\
\hline IIIA & $\mathrm{T} 1, \mathrm{~T} 2, \mathrm{~N} 1, \mathrm{M} 0$ \\
\hline IIIB & $\mathrm{T} 3, \mathrm{~T} 4, \mathrm{~N} 1, \mathrm{M} 0$ \\
\hline IIIC & Hvaða T sem er, N2, M0 \\
\hline IVA & Hvaða T sem er, N0, M1a, G1 \\
\hline IVB & $\begin{array}{l}\text { Hvaða T sem er, N0, M1a, G2,G3 } \\
\text { Hvaða T sem er, N1,N2, M1a, hvaða G sem er }\end{array}$ \\
\hline IVC & Hvaða T sem er, hvaða N sem er, M1b, hvaða G sem er \\
\hline
\end{tabular}

var 15 mánuðir (bil: 0-158). Upplýsingar um dánardag sjúklinga voru fengnar úr pjóðskrá. Upplýsingar um hverjir létust úr krabbameini í botnlanga voru fengnar hjá Krabbameinsskrá Íslands. Við útreikninga á aldursstöðluðu nýgengi miðað við Evrópustaðal WHO var notast við fólksfjöldatölur frá Hagstofu Íslands og við Kaplan-Meier-lifunargreiningu var notað tölfræðiforritið R statistics 2.10.1 fyrir Windows. Fengin voru leyfi frá Persónuvernd (tilvísunarnúmer: 2009121152LSL), vísindasiðanefnd (tilvísunarnúmer: VSNb2010010006/031), lækningaforstjóra Landspítala og Fjórðungssjúkrahússins á Akureyri, Krabbameinsskrá Íslands og lífsýnasafni Landspítala í meinafræði.

\section{Niðurstöður}

Á rannsóknartímabilinu greindust 22 sjúklingar með kirtilkrabbamein í botnlanga, 11 konur og 11 karlar. Miðgildi aldurs sjúklinga var 63 ár (bil: 30-88). Aldursstaðlað nýgengi samkvæmt Evrópustaðli WHO var 0,4 af hverjum 100.000 íbúum á ári. Algengasta einkennið var kviðverkur $(n=18)$, par af tíu í hægri neðri fjórðungi, en átta sjúklingar töldust hafa klínísk einkenni botnlangabólgu (tafla II). Allir sjúklingar utan einn voru greindir í aðgerð (n=5) eða við vefjarannsókn $(n=16)$ en einn sjúklingur var greindur við krufningu.

Flestir höfðu sjúkdóm á stigi IV, eða 13 sjúklingar (mynd 1). Einn sjúklingur greindist samtímis með æxli í bugaristli og annar sjúklingur greindist ári eftir greiningu botnlangakrabbameins með krabbamein í nýra.

Allir sjúklingar nema sá sem var greindur við krufningu fóru í skurðaðgerð (mynd 2). Ellefu sjúklingar fóru í brottnám á hægri hluta ristils en sex peirra höfðu áður farið í botnlangatöku par sem greindist óvænt botnlangakrabbamein. Einn sjúklingur fór í brottnám á botnristli og dausgarnarenda og einn í ristilúrnám. Einn sjúklingur fór í botnlangatöku eingöngu en pegar átti að framkvæma brottnám á hægri hluta ristils greindust hjá honum dreifð meinvörp. Einn sjúklingur fór í brottnám á bugaristli vegna æxlis. Fjórir sjúklingar fóru í botnlangatöku og aðra aðgerð, allir með dreifan sjúkdóm (sjá töflu I). Hjá premur sjúklingum með dreifðan sjúkdóm var eingöngu tekið sýni til vefjagreiningar, par af einum sem greindist við krufningu. Einn sjúklingur sem kom inn með stíflu í ristli reyndist hafa dreifðan æxlisvöxt og var allur ristill fjarlægður.

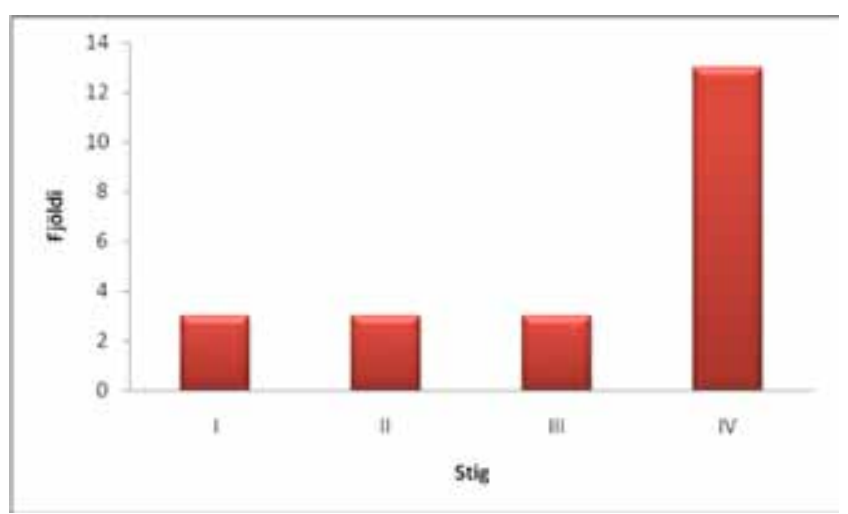

Mynd 1. Stigun við greiningu hjá sjúklingum með krabbamein í botnlanga. 
Tafla II. Faraldsfræði, einkenni og meinafræði sjúklinga sem greindust með botnlangakrabbamein 1990-2009.

\begin{tabular}{|c|c|c|c|c|c|c|c|}
\hline $\begin{array}{l}\text { Nr. / } \\
\text { greiningarár }\end{array}$ & Kyn & $\begin{array}{l}\text { Aldur } \\
\text { (ár) }\end{array}$ & Einkenni & Vefjagerð & $\begin{array}{l}\text { Proskunargráða } \\
\text { æxlis }\end{array}$ & Skurðaðgerð & Lyfjameðferð \\
\hline $1 / 1990$ & Kona & 54 & $\begin{array}{l}\text { Paninn kviður, uppköst, hiti, } \\
\text { pyngdartap }\end{array}$ & Sigðfrumukrabbamein & 3 & $\begin{array}{c}\text { Sýnataka til } \\
\text { vefjagreiningar }\end{array}$ & Líknandi \\
\hline 2/1991 & Karl & 66 & $\begin{array}{l}\text { Kviðverkur, fyrirferð í hægri } \\
\text { neðri fjórðungi }\end{array}$ & Kirtilkrabbamein & 3 & $\begin{array}{c}\text { BHR, brottnám á hluta } \\
\text { af skeifugörn og hægra } \\
\text { nýra }\end{array}$ & Líknandi \\
\hline 3/1991 & Karl & 34 & Paninn kviður, pyngdartap & Slímkrabbamein & 1 & $\begin{array}{l}\text { Sýnataka til } \\
\text { vefjagreiningar }\end{array}$ & Líknandi \\
\hline $4 / 1993$ & Kona & 32 & Kviðverkur, ógleði, uppköst & Slímkrabbamein & 1 & $\begin{array}{l}\text { botnlangataka, brottnám } \\
\text { á eggjastokkum, } \\
\text { brottnám á garnahengju }\end{array}$ & $\mathrm{Nei}$ \\
\hline $5 / 1994$ & Karl & 62 & $\begin{array}{l}\text { Kviðverkur, ógleði, lystarleysi, } \\
\text { paninn kviður, hiti }\end{array}$ & Slímkrabbamein & 1 & $\begin{array}{l}\text { Sýnataka til } \\
\text { vefjagreiningar }\end{array}$ & $\mathrm{Nei}$ \\
\hline 6/1995 & Kona & 69 & $\begin{array}{l}\text { Kviðverkur, ópægindi við } \\
\text { pvaglát, paninn kviður, } \\
\text { ógleði, hiti, lystarleysi }\end{array}$ & Slímkrabbamein & 2 & $\begin{array}{c}\text { Botnlangataka, brottnám } \\
\text { á eggjastokkum, } \\
\text { brottnám á garnahengju }\end{array}$ & $\mathrm{Nei}$ \\
\hline 7/1995 & Karl & 81 & Kviðverkur & $\begin{array}{l}\text { Blandað krabbalíkisæxli } \\
\text { af slímfrumugerð og } \\
\text { slímkrabbamein }\end{array}$ & 1 & $\begin{array}{l}\text { Brottnám á botnristli og } \\
\text { dausgarnarenda }\end{array}$ & $\mathrm{Nei}$ \\
\hline 8/1996 & Karl & 43 & Kviðverkur, pyngdartap & Kirtilkrabbamein & 1 & Botnlangataka, BHR & $\mathrm{Nei}$ \\
\hline 9/1996 & Kona & 49 & Kviðverkur & Kirtilkrabbamein & 2 & $\begin{array}{l}\text { BHR, botnlangataka, } \\
\text { legnám, brottnám á } \\
\text { hluta af skeifugörn }\end{array}$ & Líknandi \\
\hline $10 / 1996$ & Kona & 79 & Kviðverkur & Kirtilkrabbamein & 2 & Botnlangataka, BHR & $\mathrm{Nei}$ \\
\hline $11 / 1997$ & Karl & 83 & Slappleiki & Slímkrabbamein & 1 & Engin & $\mathrm{Nei}$ \\
\hline $12 / 1998$ & Karl & 57 & $\begin{array}{l}\text { Kviðverkur, fyrirferð í hægri } \\
\text { neðri fjórðungi, hiti }\end{array}$ & Kirtilkrabbamein & 2 & BHR, botnlangataka & Viðbótarmeðferð \\
\hline 13/1999 & Kona & 43 & Kviðverkur & $\begin{array}{c}\text { Slímæxli af óvissri illkynja } \\
\text { lífhegðan }\end{array}$ & 1 & $\mathrm{BHR}$ & $\mathrm{Nei}$ \\
\hline $14 / 2001$ & Kona & 76 & $\begin{array}{l}\text { Kviðverkur, paninn kviður, } \\
\text { pyngdartap }\end{array}$ & Kirtilkrabbamein & 1 & $\begin{array}{l}\text { Botnlangataka, brottnám } \\
\text { á eggjastokkum, } \\
\text { sýnataka úr garnahengju }\end{array}$ & $\mathrm{Nei}$ \\
\hline $15 / 2002$ & Kona & 88 & $\begin{array}{l}\text { Kviðverkur, uppköst, } \\
\text { niðurgangur }\end{array}$ & $\begin{array}{c}\text { Slímæxli af óvissri illkynja } \\
\text { lífhegðan }\end{array}$ & 1 & $\mathrm{BHR}$ & $\mathrm{Nei}$ \\
\hline $16 / 2007$ & Karl & 78 & Kviðverkur & Kirtilkrabbamein & 2 & $\begin{array}{c}\text { Botnlangataka, brottnám } \\
\text { á bugaristli }\end{array}$ & $\mathrm{Nei}$ \\
\hline $17 / 2008$ & Karl & 72 & Kviðverkur, ógleði, uppköst & Kirtilkrabbamein & 3 & Botnlangataka & Líknandi \\
\hline $18 / 2008$ & Karl & 73 & $\begin{array}{l}\text { Breytingar á hægðavenjum, } \\
\text { hægðastopp }\end{array}$ & Sigðfrumukrabbamein & 3 & Ristilbrottnám & Líknandi \\
\hline $19 / 2009$ & Kona & 52 & Kviðverkur, ógleði, uppköst & $\begin{array}{l}\text { Blandað kirtilkrabbamein } \\
\text { og sigðfrumukrabbamein }\end{array}$ & 3 & $\begin{array}{l}\text { BHR, brottnám á } \\
\text { eggjastokkum og } \\
\text { legnám }\end{array}$ & Líknandi \\
\hline $20 / 2009$ & Kona & 64 & $\begin{array}{c}\text { Kviðverkur, pyngdartap, tíð } \\
\text { pvaglát }\end{array}$ & Slímkrabbamein & 1 & $\begin{array}{l}\text { BHR, brottnám á hluta } \\
\text { af pvagblöðru og } \\
\text { smágirni }\end{array}$ & Viðbótarmeðferð \\
\hline $21 / 2009$ & Karl & 43 & Kviðverkur & Sigðfrumukrabbamein & 3 & Botnlangataka, BHR & Viðbótarmeðferð \\
\hline $22 / 2009$ & Kona & 30 & $\begin{array}{c}\text { Kviðverkur, fyrirferð í hægri } \\
\text { neðri fjórðungi }\end{array}$ & Slímkrabbamein & 1 & Botnlangataka, BHR & Viðbótarmeðferð \\
\hline
\end{tabular}

Hjá fimm konum voru leg og eggjastokkar fjarlægðir vegna gruns um frumsjúkdóm par og í premur tilfellum var gert brottnám á garnahengju (omentum). Einn sjúklingur var með vöxt yfir á pvagblöðru og var hluti pvagblöðrunnar fjarlægður samtímis brottnámi á hægri hluta ristils. Pessu tilfelli hefur pegar verið lýst sérstaklega. ${ }^{12}$ Tólf sjúklingar fengu lyfjameðferð, fimm sem viðbótarmeðferð og sjö sem meðferð við dreifðum sjúkdómi. Einn sjúklingur sem hafði dreifðan sjúkdóm við greiningu fékk lífhimnubundna lyfjameðferð (intraperitoneal chemotherapy) og hjá einum sjúklingi var fyrirhuguð heit lífhimnubundin lyfjameðferð (heated intraperitoneal chemotherapy (HIPEC)) erlendis.

Botnlangaæxlin voru af fjórum mismunandi vefjagerðum (tafla 
Tafla III. Fylgikvillar sjúklinga sem fóru íađgerð vegna krabbameins i botnlanga.

\begin{tabular}{lc}
\hline Fylgikvillar & Fjöldi (\%) \\
\hline Pvagærasýking & $2(10)$ \\
\hline Lungnabólga & $2(10)$ \\
\hline Parmalömun & $2(10)$ \\
\hline Gallstasi & $1(5)$ \\
\hline Lömun á pvagblöðru & $1(5)$ \\
\hline
\end{tabular}

II), átta sjúklingar höfðu kirtilkrabbamein, sjö slímkrabbamein, prír sigðfrumukrabbamein, einn blandað krabbalíkisæxli af slímfrumugerð og slímkrabbamein og loks einn með blandað kirtilkrabbamein og sigðfrumukrabbamein. Tveir sjúklingar greindust með slímæxli af óvissri illkynja lífhegðan (mucinous adenocarcinoma tumour of uncertain malignant potential). Flestir höfðu vel proskuð æxli, eða tíu, fimm miðlungs og sjö illa proskuð æxli. Hjá átta sjúklingum var æxlið sýnilega upprunnið î kirtilsepaæxli, hjá fimm í totumyndandi sepaæxli (villous adenoma), hjá tveimur í sagtenntu kirtilsepaæxli (serrated adenoma) og hjá einum í kirtilmyndandi sepaæxli (tubular adenoma). Fjórir sjúklingar (18\%) höfðu skinuslímhlaup (pseudomyxoma peritoneii), allir með slímkrabbamein.

Sex sjúklingar (29\%) fengu fylgikvilla í kjölfar aðgerðar sem sýndir eru í töflu III. Einn sjúklingur fór í enduraðgerð vegna gallstasa sem hann fékk í kjölfar brottnáms á hægri hluta ristils og hluta skeifugarnar vegna yfirvaxtar krabbameinsins. Einn sjúklingur með dreifðan sjúkdóm lést átta dögum eftir skurðaðgerð og skurðdauði var pví 4,8\%. Sjúkdómssértæk fimm ára lifun var 54\% (mynd 3). Eins árs og fimm ára heildarlifun var 75 og 44\% (mynd 4). Miðgildi lifunar hjá peim átta sem létust vegna botnlangakrabbameins var 9,3 mánuðir (bil: átta dagar-90 mánuðir).

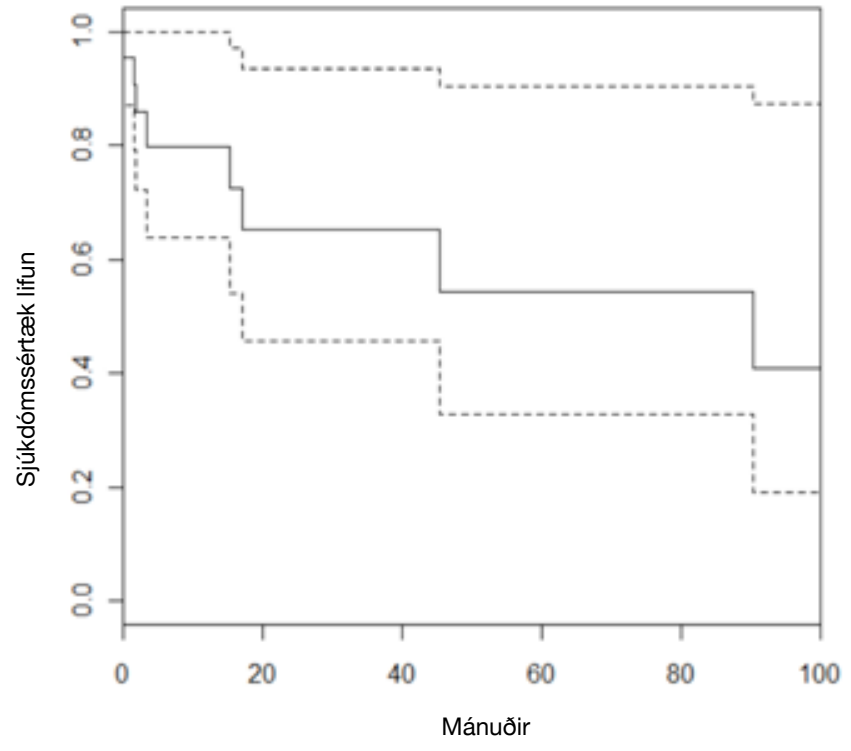

Mynd 3. Sjúkdómssértæk lifun sjúklinga með botnlangakrabbamein með 95\% öryggisbilum. Fimm ára lifun er 54\% (Kaplan Meier).

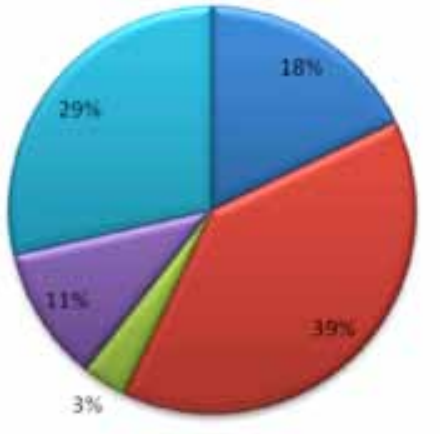

u Botnlangataka

a Brottnám á hagri hluta ristils

$\Delta$ Brottnam a botnristli og dausgamarenda

as vinataka

unnur adgerd

Mynd 2. Skurðaðgerðir vegna krabbameins í botnlanga. Átta sjúklingar fóru í aðra aðgerð auk brottnáms á botnlanga eða brottnáms á hægri hluta ristils. Flestir, eða fjórir sjúklingar, fóru í brottnám á legi og eggjastokkum og prír í brottnám á garnahengju (omentum).

\section{Umræða}

Krabbamein í botnlanga er sjaldgæft en í pessari rannsókn var aldursstaðlað nýgengi samkvæmt Evrópustaðli WHO 0,4 á hverja 100.000 íbúa á ári. Í fyrri rannsókn á botnlangakrabbameinum hér á landi fyrir tímabilið 1974-1989 var nýgengið 0,2 á hverja 100.000 á ári en í rannsókn frá Bandaríkjunum fyrir árin 19731998 var nýgengið einungis 0,12 á hverja 1.000 .000 á ári. ${ }^{4,13}$

Meðalaldur sjúklinga var 60 ár sem er sambærilegt við aðrar rannsóknir. 3, 5, 8, 13 Hins vegar var meðalaldur tæpum fimm árum hærri en í fyrri rannsókn hér á landi. ${ }^{4}$ Kynjahlutföll fyrir heildina voru jöfn en sumar rannsóknir hafa bent til að slímkrabbamein sé algengara í konum og hlutfallið allt að 3:1, en í okkar rannsókn var hlutfallið 1,7:1 fyrir slímkrabbamein. Í fyrri íslensku rannsókninni var hlutfallið 2,5:1. ${ }^{4}$ Kviðverkur var langalgengasta einkennið eða hjá rúmum $80 \%$ sjúklinga. 36\% höfðu einkenni botnlangabólgu sem er sambærilegt við rannsókn par sem 37,2\% höfðu einkenni

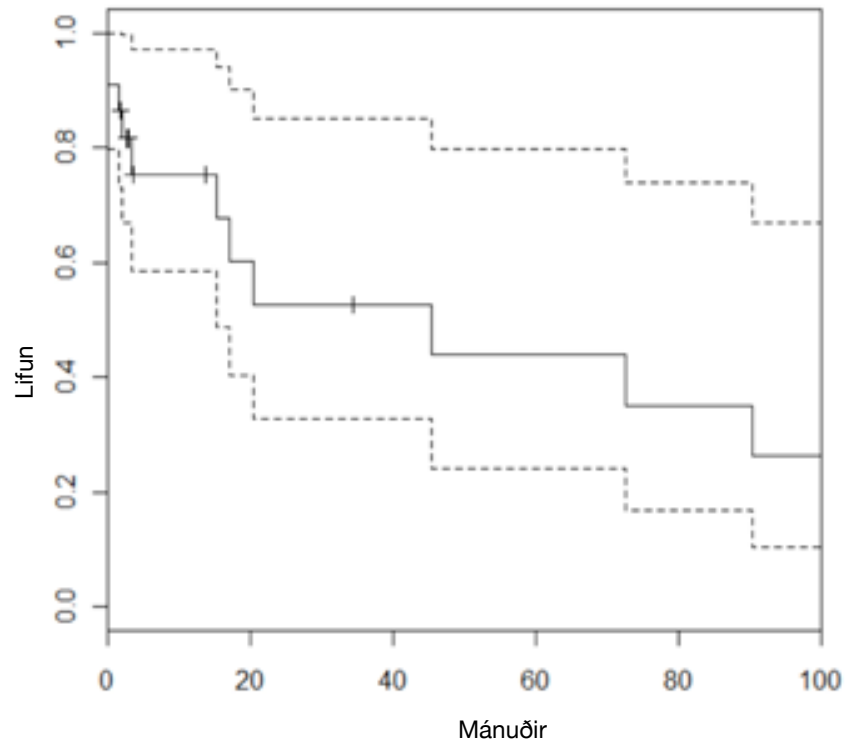

Mynd 4. Heildarlifun sjúklinga með botnlangakrabbamein með 95\% öryggisbilum. Fimm ára lifun er $44 \%$ (Kaplan Meier). 
bráðrar botnlangabólgu. ${ }^{14}$ Petta er lægra hlutfall en í fyrri rannsókn par sem 57\% höfðu slík einkenni. ${ }^{4}$ Engir sjúklingar greindust með krabbamein í botnlanga fyrir aðgerð en petta á einnig við um fyrri rannsóknina hér á landi og flestar aðrar sambærilegar rannsóknir., 6

Krabbameini annars staðar í meltingarvegi, einkum ristli, hefur verið lýst og í einni rannsókn voru 35\% með slík æxli og í annarri voru 13\% sjúklinga með æxli í ristli.6, 15 Í okkar rannsókn greindist einn sjúklingur með krabbamein í bugaristli samtímis greiningu á botnlangakrabbameininu. Einn sjúklingur hafði áður fengið krabbamein í eggjastokka og annar sjúklingur fékk nýrnakrabbamein eftir greiningu botnlangakrabbameins. Par sem eitlastöðvar botnlanga eru pær sömu og fyrir botnristil, botnlanga og dausgarnarenda hefur verið mælt með brottnámi á hægri hluta ristils sem meðferð við kirtilkrabbameini í botnlanga. ${ }^{9}$ Röksemdin fyrir pessu hefur verið að hátt hlutfall sjúklinga, eða allt að $25 \%$, sé með eitlameinvörp. ${ }^{6,14}$ Petta hefur verið umdeilt, einkum fyrir slímkrabbamein par sem hlutfall sjúklinga með eitlameinvörp er mun lægra en sjúklinga með kirtilkrabbamein, eða 4,2\% samkvæmt rannsókn GonzalezMoreno. ${ }^{16}$ Sugerbaker mælir með varðeitlatöku og séu peir eitlar jákvæðir skuli framkvæma brottnám á hægri hluta ristils. ${ }^{10}$ Sumar rannsóknir hafa sýnt fram á betri lifun ef brottnám var framkvæmt á hægri hluta ristils samanborið við botnlangatöku eingöngu, en munur á fimm ára lifun var 63\% á móti $20 \%{ }^{6}$ Gonzalez-Moreno skoðaði 501 sjúkling með kirtilkrabbamein í botnlanga. Allir sjúklingarnir höfðu útsæði í lífhimnu og fóru allir í aðgerð par sem allur sjáanlegur æxlisvefur var fjarlægður og síðan beitt heitri lífhimnubundinni lyfjameðferð. Alls fóru 198 í botnlangatöku, 280 í brottnám á hægri hluta ristils. Sjúklingar sem fóru í brottnám á hægri hluta ristils höfðu ekki betri lifun en peir sem fóru einvörðungu í botnlangatöku. ${ }^{16}$

Í okkar rannsókn fóru allir sjúklingar nema tveir sem greindust á stigi I-III (sjö af níu) í brottnám á hægri hluta ristils. Tveir sjúklingar fóru í brottnám á botnristli og dausgarnarenda (ileocoecal resection) annars vegar, og botnlangatöku ásamt brottnámi á æxli í bugaristli hins vegar. Petta er svipað hlutfall og kemur fram í pýskri rannsókn par sem 71,4\% sjúklinganna fengu viðeigandi meðferð. ${ }^{14}$
Fimm ára lifun var einungis 44\% sem er lægra en í rannsókn Nitecki par sem fimm ára heildarlifun var 55\%. Munurinn skýrist líklega af pví að hlutfall sjúklinga með sjúkdóm á stigi IV í okkar rannsókn var 54\%, samanborið við $29 \%$ hjá Nitecki. ${ }^{6}$ Heildar fimm ára lifun í pýskri rannsókn sem náði til 144 sjúklinga með kirtilkrabbamein í botnlanga var $49,2 \%$ en í henni voru 25\% sjúklinga með sjúkdóm á stigi IV. Í íslensku rannsókninni fyrir árin 1974-1989 var ekki reiknuð fimm ára lifun en í peirri rannsókn voru fjórir af sjö sjúklingum látnir vegna síns sjúkdóms.

Í okkar rannsókn voru tveir sjúklingar með slímæxli af óvissri illkynja lífhegðan á sama stað. Petta eru æxli par sem erfitt er að ákvarða með vissu hvort um góðkynja eða illkynja æxli sé að ræða. Skilyrði sem parf að uppfylla til að æxli teljist til pessa flokks eru vel sérhæfð slímpekja sem prýstir djúpt á undirliggjandi vefi án augljóss ífarandi vaxtar, eða slím í botnlangavegg eða utan hans án augljóss innvaxtar en með tapi á vöðvaslímhimnu (muscularis mucosae). ${ }^{17,} 18$

Fyrirhugað var að senda einn sjúkling í rannsókninni í HIPECmeðferð erlendis. Meðferðin felur í sér aðgerð par sem allur æxlisvefur er fjarlægður ásamt lífhimnu (par sem æxlisvefur er til staðar) og síðan er kviðarholið fyllt með krabbameinslyfjum (mitomycin C, doxorubicin) sem hafa verið hituð upp í $40^{\circ} \mathrm{C}$. Sjúklingnum er síðan velt í 90 mínútur til að tryggja að krabbameinslyfin nái til allra svæða í kviðarholinu. ${ }^{10}$ Árangur pessarar meðferðar hefur verið góður, 80\% lifun eftir 20 ár fyrir krabbamein af lágri gráðu og 45\% fyrir krabbamein af hárri gráðu ef tekst að fjarlægja allan æxlisvef. ${ }^{10}$

Helstu vankantar pessarar rannsóknar eru að hún er afturskyggn, byggist á upplýsingum sem teknar eru úr sjúkraskrám og pví ekki unnt að sannreyna pær.

Helsti styrkur rannsóknarinnar er að vefjasýni frá öllum æxlum voru endurskoðuð og metin af einum meinafræðingi. Öll tilfellin eru pess vegna staðfest með endurskoðun á vefjasýnum og pví eru allar upplýsingar er lúta að vefjagerð og proskunargráðu æxlis skráðar beint af rannsakendum. Rannsóknin nær til allra greindra tilfella hérlendis og pó svo að tilfellin séu fá, gefur hún áreiðanlega mynd af pessum sjúkdómi á Íslandi á 20 ára tímabili.

\section{Heimildir}

1. McGory ML, Maggard MA, Kang H, O'Connell JB, Ko CY Malignancies of the appendix: beyond case series reports. Dis Colon Rectum 2005; 48: 2264-71.

2. Chang $P$, Attiyeh FF. Adenocarcinoma of the appendix. Dis Colon Rectum 1981; 24: 176-80.

3. Beger A. Ein Fall von Krebs des Wurmfortsatzes. Berl Klin Wochenschr 1882; 19: 616-8.

4. Nielsen GP, Isaksson HJ, Finnbogason H, Gunnlaugsson GH. Adenocarcinoma of the vermiform appendix. A population study. APMIS 1991; 99: 653-6.

5. Connor SJ, Hanna GB, Frizelle FA. Appendiceal tumors: retrospective clinicopathologic analysis of appendiceal tumors from 7,970 appendectomies. Dis Colon Rectum 1998; 41: 75-80.

6. Nitecki SS, Wolff BG, Schlinkert R, Sarr MG. The natural history of surgically treated primary adenocarcinoma of the appendix. Ann Surg 1994; 219: 51-7.

7. Oya S, Miyata K, Yuasa N, et al. Early carcinoma of the appendix vermiformis. Dig Endosc 2009; 21: 53-5.
8. Mistry R, Ananthakrishnan K, Hamid BN, Powell C, Foster GE. Appendiceal carcinoma masquerading as recurrent urinary tract infections: case report and review of literature. Urology 2006; 68: 428 e1-3.

9. Cortina R, McCormick J, Kolm P, Perry RR. Management and prognosis of adenocarcinoma of the appendix. Dis Colon Rectum 1995; 38: 848-52.

10. Sugarbaker PH. Epithelial appendiceal neoplasms. Cancer J 2009; 15: 225-35.

11. Cancer, AJCC (American Joint Committee on Cancer) Cancer Staging Manual, 7th ed. Springer, New York 2010.

12. Vidarsdottir $\mathrm{H}$, Vidarsdottir $\mathrm{H}$, Moller $\mathrm{PH}$, Benediktsdottir KR, Geirsson G. Adenocarcinoma of the appendix with a fistula to the urinary bladder. Scand J Urol Nephrol 2010; 44. 354-6.

13. McCusker ME, Coté TR, Clegg LX, Sobin LH. Primary malignant neoplasms of the appendix: a population-based study from the surveillance, epidemiology and end-results program, 1973-1998. Cancer 2002; 94: 3307-12.
14. Benedix F, Reimer A, Gastinger I,et al. Primary appendiceal carcinoma--epidemiology, surgery and survival: results of a German multi-center study. Eur J Surg Oncol 2010; 36: 763-71.

15. Smeenk RM, van Velthuysen ML, Verwaal VI, Zoetmulder FA. Appendiceal neoplasms and pseudomyxoma peritonei: a population based study. Eur J Surg Oncol 2008; 34: 196-201.

16. Gonzalez-Moreno S, Sugarbaker PH. Right hemicolectomy does not confer a survival advantage in patients with mucinous carcinoma of the appendix and peritoneal seeding. Br J Surg 2004; 91: 304-11.

17. Carr NJ, McCarthy WF, Sobin LH. Epithelial noncarcinoid tumors and tumor-like lesions of the appendix. A clinicopathologic study of 184 patients with a multivariate analysis of prognostic factors. Cancer 1995; 75: 757-68.

18. Misdraji J. Appendiceal mucinous neoplasms: controversial issues. Arch Pathol Lab Med 2010; 134: 864-70. 


\section{ENGLISH SUMMARY}

\section{Adenocarcinoma of the appendix in Iceland 1990-2009. A population based study}

Vidarsdottir H, Jonasson JG, Moller PH

Objective: Adenocarcinoma of the appendix is less than $0.5 \%$ of all gastrointestinal cancers. The aim of this study was to analyse the incidence, symptoms, pathology and treatment of appendiceal adenocarcinoma in a well defined cohort as well as the prognosis of the patients.

Materials and methods: This is a retrospective study on all patients diagnosed with adenocarcinoma of the appendix in Iceland from $1990-2009$.

Information on epidemiological factors, survival and treatment was collected. All histological material was reviewed. Overall survival was estimated with median follow up of 15 months (range, 0-158).

Results: A total of 22 patients were diagnosed with appendiceal adenocarinoma in the study period (median age 63 yrs, range: $30-88,50 \%$ males). Agestandardized incidence was $0.4 / 100,000 /$ year. The most common symptom was abdominal pain ( $n=10)$. Eight patients had clinical signs of appendicitis. Most patients were diagnosed at operation or at pathological examination but one patient was diagnosed at autopsy. Five patients had an appendectomy and 11 a right hemicolectomy. One patient was not operated on and in three patients only a biopsy was taken. Twelve patients had chemotherapy and seven of them for metastatic disease. Eight patients had adenocarcinoma, seven mucinous adenocarcinoma, three signet ring adenocarcinoma, one mixed goblet cell carcinoid and mucinous adenocarcinoma,one mixed adenocarcinoma and signet ring adenocarcinoma and two a mucinous tumour of unknown malignant potential. In eight cases the tumor originated in adenoma. Most of the patients had a stage IV disease ( $\mathrm{n}=13$ ), three stage III, three stage II and three stage I. Operative mortality was $4.8 \%(n=1)$. Disease specific five year survival was $54 \%$ but overall five year survival was $44 \%$ respectively.

Conclusion: Adenocarcinoma of the appendix is a rare disease. No patients were diagnosed pre-operatively. Over half of the patients presented with stage IV disease.

Key words: Appendix, adenocarcinoma, symptoms, pathology, treatment, survival.

Correspondence: Páll Helgi Möller, pallm@landspitali.is 